\author{
Review Article
}

\title{
A COMPREHENSIVE REVIEW ON THE NUTRITIONAL AND MEDICINAL SIGNIFICANCE OF KUSHMANDA OR ASH GOURD AS PER AYURVEDA
}

\section{Nimmy V S}

Assistant Professor, Department of Dravyaguna Vijnanam, Vaidyaratnam Ayurveda College, Ollur, India.

\begin{tabular}{l}
\hline Article info \\
\hline Article History: \\
Received: 27-09-2021 \\
Revised: 13-10-2021 \\
Accepted: 11-11-2021 \\
\hline KEYWORDS: \\
Kushmanda, Ash \\
gourd, Benincasa \\
hispida.
\end{tabular}
\begin{abstract}
Ayurveda stresses on the use of herbs as both food and medicine based on their nutritional and medicinal values respectively. While the Rasa (taste) of the medicinal plant determines its dietary value, the Veerya (potency) bestows its therapeutic actions. Kushmanda or Ash gourd (Benincasa hispida (Thunb.) Cogn.) is such a fruit appraised in Ayurveda for both its medicinal and nutritive values. It is of utmost importance to showcase the properties and actions of this indigenous herb as it is easily available, safe and affordable to the common people. Kushmanda is used in managing ulcers, epilepsy, urinary disorders and in treating poisoning. The seeds and fruit juice of Kushmanda is claimed to be nootropic (Medhya) and is recommended in Ayurveda for enhancing memory and other cognitive functions. Experimental studies prove that Kushmanda possesses multitude of actions including antidiabetic, anti-inflammatory, antioxidant, hypolipidemics, hypoglycaemic etc. A thorough review shows that the presence of phenols, triterpenes, sterols, and glycosides of ash gourd makes it useful for treatment of ulcers, inflammation, epilepsy and other nervous disorders. Further elaborate clinical studies need to be undertaken to explore and strengthen the claims on efficacy of Benincasa hispida (Thunb.) Cogn. in nervous disorders, ulcers and diabetes.
\end{abstract}

\section{INTRODUCTION}

The fruit of Benincasa hispida (Thunb.) Cogn. of Cucurbitaceae family commonly known as Ash gourd and "Kushmanda" in Ayurveda is relevant as nutritive source as well as a medicine. Its use in psycho-somatic disorders, ulcer, urinary disorders and digestive disorders has been well explored in Ayurveda. Ash gourd is cultivated throughout India and has high market demand owing to its nutritional value and health benefits. It is an important warm-season cucurbit vegetable, grown for its succulent hairy fruits, used as a vegetable, in confectionery and Ayurvedic medicinal preparations. The current generation relates to Ash gourd as the miracle fruit that helps detoxify the body and helps weight loss. The social media has been popularizing the use of the fruit juice as part of dieting techniques.

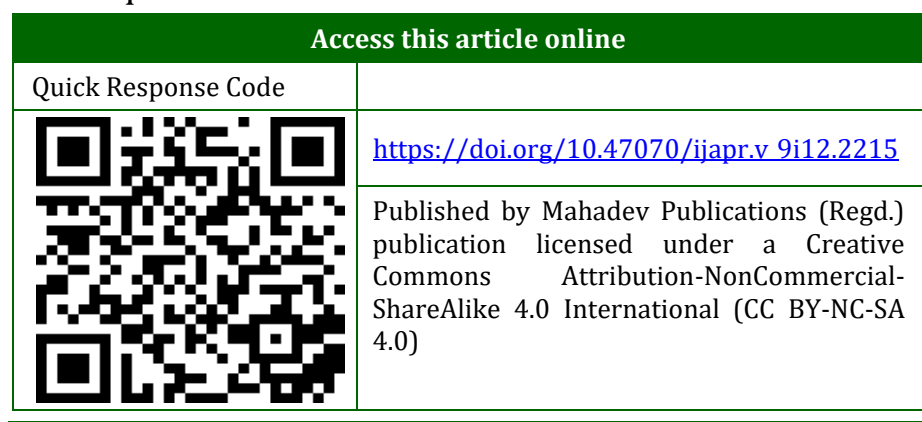

The sweet delicacy that is known to the world as "Agra petha", is also prepared from ash gourd. Commonly known as winter melon, wax gourd, white pumpkin, and Chinese watermelon, Kushmanda is native to parts of Southern Asia.

Ayurveda classical textbooks and Nighantus describe in length about the properties, actions, therapeutic uses and synonyms of the herb. Brhat Trayi have described Kushmanda under "Saka varga" [1]. Acharya Vagbhata accepts Kushmanda as the best among Valli phala (creepers) ${ }^{[2]}$. Classical textbooks also advocate the use Kushmanda for various ailments including Mutrakriccha, Apasmara, Unmada, Visha, Amlapitta etc ${ }^{[3]}$ which will be dealt in detail further in this article. Keraleeya visha granthas like Prayogasamucchaya and Visha Vaidya jyosnika have mentioned its utilities in poisoning in both Sthavara (vegetable poisons) and Jangama vishas (animal poisons) [4]. Bhava Misra has included Kushmanda as a potent Medhya Rasayana[5]. Kushmanda rasayana, Kushmanda Ghrita, Kusmanda avaleha, Dhatriyadi ghrita and Vastiamayantaka ghrita are some of the important formulations of the drug as per Ayurveda. 


\section{Plant Description[6]}

Benincasa hispida (Thunb.) Cogn. is a large trailing gourd climbing by means of tendrils; stem is stout, angular and hispid. The leaves have a reniformorbicular shape with 5-7 lobes and are 4-6 inches length. The hairy lobes are ovate-triangular in shape. Flowers are yellow, unisexual, male peduncle 7.5$10 \mathrm{~cm}$ long, female peduncle shorter. The fruits are broadly cylindrical, $30-45 \mathrm{~cm}$ long, hairy throughout, ultimately covered with a waxy bloom. This waxy bloom disappeared when the fruit is fully mature.

Flowering \& Fruiting: June-October. Harvesting of the mature fruits starts in 90-100 days after sowing and may continue up to 150 days after sowing.

Parts used[1]: Fruit, Seeds, seed oil, leaves.

Synonyms[1]: Kushmanda, Pushpaphala, Pitaphushpa, Karkaru, Aaru

\section{Vernacular Names[7]}

Hindi - Kumhra, Pani kumhra, Petha

Kannada - Bood kumbala kayi

Malayalam - Elavan, Kumbalam, Neyakumbalam

Marathi - Kohla

Punjab - Petha

Sanskrit - Kushmanda

Tamil - Kalyana pooshni, Pushanikai

Telugu - Budida-gummadi

\section{Properties and Action}

Charakacharya describes Pakva Kushmanda (mature fruit) to be having Madhura rasa, alkaline nature and light to digest (Laghu), having diuretic and laxative action and Tridosahara property.

Susruta acharya details the properties of Balam (immature fruit) and Pakwa kushmanda (mature fruit) and also delineates the properties of Kusmanda beeja tailam[8]. Susruta Samhita describes the immature fruit to be alleviating Pitta dosa and possessing nootropic and Kapha increasing properties. The mature fruits are said to increase digestive fire (Deepanam), diuretic (Vasti shodanam), appetiser (Hrdyam), alleviating Tridosa and useful in psychiatric disorders (Chetoroga haram $)^{[8]}$. It is also described to be a wholesome food or Pathya ahara which is of utmost benefit to health. According to Acharya Susrutha the seed oil of Kushmanda is sweet in taste (Madhura rasa) and after taste (Madhura vipaka) and has a cold potency (Seetha veerya). The seed oil pacifies Vata and Pitta dosas and acts as laxative-diuretic (Srit vit-mutra), it may cause blockage of Srotas (Abhishyandi), and diminishment of digestive fire (Agni Saada).

Detailed accounts of the properties and action of Kushmanda are available in the Nighantus of Ayurveda. While generally describing the fruit to be Guru, Brimhana (nourishing), Vrisya (aphrodisiac), and alleviating Pitta-rakta; Bhava prakasa Nighantu details the difference in action of Kushmanda based on stage of ripening as follows ${ }^{[5]}$ :

Unripe fruit or Bala Kushmanda: Alleviates Pitta and is cold in potency

Half ripened fruit (Madhyama): Aggravates Kapham

Mature fruit (Vridham): It is not too cold in potency and has Swadu-kshara rasa and Laghu property. It is also said to be Deepana (digestive), Vasti suddhikara (diuretic), Chetorogaharam (useful in psychiatric disorders) and Tridosaharam.

The same properties and actions have been accepted in Dhanwantari Nighantu, Raja Nighantu and Priya Nighantu.

\section{Prayoga}

\section{Action of Kushmanda as Medhya Rasayana}

The fruit of Benincasa hispida is acclaimed to be Medya or possessing nootropic action. Kushmanda is the main ingredient of "Kusmanda lehyam" and Kushmanda ghrita popular Ayurvedic medicines, widely used, in psychiatric and nervous disorders. Numerous studies have been conducted to explore the action of Kushmanda Grhita and Kushmanda lehya in psychiatric and nervous disorders. Kushmanda ghritaa medicated ghee processed using paste of root of Yastimadhu (Glycyrrhiza glabra) in fruit juice of Kushmanda is indicated in epilepsy (Apasmara) and is described to promote clarity in voice (Swara), intellect (Dhee), and speech (Vaak). (A.H.Ut.8/28) Studies prove that Kusmanda Ghrita has anti depressant action and has shown to improve the depressive illness in patients[9]. In another study Kushmandadi Ghrita showed significant results in the management Chittodvega (anxiety disorders)[10]. The action has been attributed to the Medhya prabhava as described in Ayurveda. On the same note, Bhaisajya ratnavalai advocates the administration of seed paste of ash gourd along with honey for 3 consecutive days for the management of Unmada. (B.R Unmada Chikitsa 24/8). There are studies that prove that fruit of Benencasa hispida has a tissue protective preventive effect as proven on colchicine induced Alzheimer's disease model via direct and indirect antioxidant activity[11].

\section{Kushmanda as Balya and Dhatu pushtikara}

Ayurveda practitioners recommend including Kushmanda fruit regularly in food for promoting weight gain, promoting strength and for its nourishing property. In traditional practice the mature fruit is administered among malnourished children to help gain weight and establish health. The fruit is cut into pieces and boiled, after draining off the water, the pulp is mixed with ghee and jaggery and administered. A Clinical trial successfully proves the efficacy of Kushmanda (Benincasa hispida) for weight gain in malnourished children[12]. 


\section{Action on Mutravaha Srotas}

Kushmanda (Benincasa hispida [Thunb.] Cong.) is said to be Basti shuddikara and the Srishta mutrakaraka[1] and Mannitol content of Kushmanda has been attributed to these functions. Thereby it acts by causing increased urinary output and excretion hence being utilized in the management of Mutrakrichra, Mutraghata etc. According to Bhaisajya ratnavali, the fruit juice of Ash gourd (Kushmanda Swarasa) given along with Yava kshara and Sarkara is useful in dealing Mutrakriccha (urine retention) and Asmari (urinary calculi). (B.R Mutrakrichha, 34/10). Experimental study of diuretic effect of seed extracts of Benincasa hispida by Lipschitz method exhibited significant diuretic activity[13]. The petroleum ether, ethanolic and aqueous seed extract proves to be antilithiatic and nephroprotective. ${ }^{[13]}$

\section{Anti-ulcer activity of Kushmanda}

Study shows that the extract of Kushmanda may be a natural drug with antiulcer activity. Kushmanda Avaleha provides strength and reduces aggravated Pitta symptoms including burning sensation, acid reflux and hyperacidity. Sharangdhar Samhita details the preparation of Kushmanda avaleha as follows: The outer skin of Kushmanda fruit is peeled and the fruit is cut into small pieces and cooked by boiling with 4 parts water. Then well-boiled pulp is strained through a clean dry cloth and pulp paste is separated. The pulp is fried with ghee till it becomes brown in color. It is then added to mixture of sugar and separated liquid. The mild heating is continued till desired appearance of Paka siddhi lakshana. (Appearance of thread like consistency when the Avaleha is kept in between thumb and index finger). Lastly powder of dry ginger, coriander seeds, cumin seeds, Malabar leaf, cardamom, pepper and cinnamon is mixed in lukewarm stage. Once Avaleha achieves room temperature, honey was added and then mixed uniformly. The administration of the medicine has been found to soothe the stomach linings, modulate the gastric secretion, and gives relief from peptic ulcer symptoms.

An experimental study has evaluated antiulcerogenic activity of different extracts of Benincasa hispida (fresh juice, supernatant and residue fraction of centrifuged juice, alcoholic and petroleum ether extract) in various experimental models including aspirin plus restraint, swimming stress, indomethacin plus histamine and serotonin-induced ulcers in rats and mice[14]. The oral feeding of different doses of the extract significantly reduced the ulcer index produced by various ulcerogens. The anti-ulcerogenic effect was dose-dependent in stress induced model of ulcer and not in other models. The study concludes that $B$. hispida probably has a CNS component in prevention of stress induced ulceration ${ }^{[14]}$.

\section{Action Against Respiratory Illness}

In the management of Hikka-Swasa, Kushmanda is indicated with lukewarm water (Koshna Jala). (B.R. Hikka- Swasa Chikitsa 16/19). Two triterpenes, namely alonusenol and multiflorenol, extracted from the methanolic extract of the Benincasa hispida fruit displayed a "mast cell stabilizing effect" and were found to have inhibitory effect on the histamine release induced by the antigen antibody reaction[15], The methanolic extract of Benincasa hispida showed protective action against histamine-induced bronchospasm probably through an antihistamine activity[16]. Similarly Kushmandaka Rasayana is a medicine that is commonly used in respiratory diseases owing to its Rasayana effect. Kushmandaka Rasayana is mentioned to be indicated in Kasa (cough), Hidhma (hiccough), Raktapitta (bleeding disorders), Kshata (injury to Pranavaha Srotas), Urakshata (injury to chest), and Jwara (fever). A study results point out that Kushmandaka Rasayana is effective in the management of chronic bronchitis when given in a dose of $10 \mathrm{~g}$ twice daily with water as Anupana for a period of 12 weeks[17]. The research signifies that the formulation is safe for consumption as safety parameters including LFT and RFT remained within normal limits during the entire period and no Adverse Drug reactions were observed in any of the patients during the trial. The effectiveness of the medicine on the symptoms of the disease was persistent on the follow-up without intervention at the end of 14 weeks. Therefore, the study concludes that Kushmandaka Rasayana can be taken for longer duration for the purpose of rejuvenation of the respiratory tract and for the prevention of progression of the disease[17].

\section{Other medicinal uses of Kushmanda}

- Acharya Sarangdhara mentions the use of Kushmanda Swarasa with Laksha Kalka in Raktakshaya, Uroghata and Kshaya Roga in Sarangdhara Samhita Madhyama khanda. (Sa.M.Kh.5/21).

- Rasa ratna sammuchchya indicates the usage of fruit juice of ash gourd (Kushmanda Swarasa) along with Vidanga and Sarkara in Prameha. (R.R.S. 17/140)

- Raktasrava in Mandali visha- kalka (paste) of ash gourd seeds along with garlic (Lashuna) is administered along with Tandulodaka. (Kriya Koumudi)

- Urine retention in Mandali visha- the Kasaya made of stem of Kushmanda along with Ela churna or Trikatu churna respectively is mentioned in Prayoga sammuchaya and Kriya koumudi for managing urine retention in Mandali visha.

- Ayurveda classic Bhaisajya ratnavali, also describes the use of ash gourd juice (Kushmanda Swarasa) 
along with jaggery (Guda) in the management of Madatyaya. (B.R. Madatyaya Chikitsa, 22/11)

\section{Other Research Updates}

Antidiabetic activity[18]: Majumdar et al. (2010) Clinical evaluation of Ash gourd fruit juice in Type 2 Diabetes patients for 21 consecutive days showed that the blood glucose levels reduced by approximately $42 \%$.

Hypoglycaemic and hypolipidemic[18]: Use of ash gourd extract produced a $60 \%$ reduction in blood glucose, plasma TGs and free fatty acids in rats (Lim,2007). The alcoholic extract of ash gourd at 200 mgkg-1body weight for 45 days reduced the blood glucose levels from 195 to 118 mgdL-1) in alloxaninduced diabetic rats than in normal rats (Battuet al., 2007).

Antioxidant property[18]: In vitro and in vivo studies indicated ash gourd fruit juice and extract have antioxidant activity, especially in the human liver and brain (Huang et al., 2004; Rao et al., 2007).Studies also prove that the fruit of Ash gourd have a tendency to decrease renal injury after ischemia or reperfusion injury of the kidney in albino rat models (Bhalodia et al.,2009).

Anti-inflammatory activity[18]: Free radical scavenging activity of ash gourd seed might have been responsible for reduction of inflammation in carrageenan- induced paw oedema in rats (Grover and Rathi, 1994).

Study proves that petroleum ether extract and Benincasa hispida seed oil inhibited testosteroneinduced hyperplasia of the prostate in experimental rats model[19]. The anti-angiogenic property of the seed extract of Benincasa hispida is proven as it inhibits the proliferation of endothelial cells induced by bFGF[20].

\section{Nutritive Value of Ash Gourd[18,21]}

Ash gourd encompasses of high-water content approximately $96 \%$ and is a rich source of dietary fibres. Dietary fibres from ash gourd have excellent prebiotic activity (Sreenivas and Lele, 2013). Though Ash gourd consumption contributes to negligible number of calories, carbohydrates, proteins and fats, it's a good source of Vitamin C, flavonoids and carotenes. The efficacy of ash gourd fruit in preventing cell damage and preventing type 2 Diabetes and heart disease may be attributed to the antioxidant property of its constituents. The functionally important bioactive and therapeutic compounds phenolics, sterols, and glycosides of ash gourd can be used for treatment of epilepsy, ulcers and other nervous disorders. The antacid action of ash gourd helps maintain body $\mathrm{pH}$ and counteracts acidity caused by some foods. Also, the unique dietary constituents promise to aid digestive function and helps attain weight loss. The fruit is also source of Magnesium,
Potassium, calcium, iron and phosphorous. Curcubitin $B$ found in ash gourd has cytotoxic and antiinflammatory activity. The triterpenes- alnusenol and multiflorenol from ash gourd are active histamine release inhibitors (Grubben and Denton,2004).

\section{CONCLUSION}

Ayurveda promotes using Kushmanda by calling it best among "Valli phala" or creepers. It is said to be brain tonic, digestant, diuretic, rejuvenative etc in classical textbooks. While going through the present research studies of the herb, it can be said without doubt that the fruit of Benincasa hispida can be utilized for its nutritive value and medicinally for preventing chronic disorders like Type 2 Diabetes and therapeutically for managing urinary disorders, psychosomatic disorders, ulcer and reproductive disorders. The anti-inflammatory, anti-oxidant, diuretic, anti-lithiathic, anti-ulcer, hypoglycemic and hypolipidemic activities of the fruit can be attributed to its chemical constituents triterpenes, sterols, glycosides, flavonoids and minerals.

\section{REFERENCES}

1. Sharma PV. Dravyaguna Vijnana, part 4, Chaukhambha Bharati Academy, Varanasi; 2006. Page 14

2. Vagbhata. Ashtanga Hrdayam sutra sthana. Varanasi: Chowkaba Krishnadas Academy; 2012

3. Dr Shastry. J.L.N. Dravya Guna Vijnana. Varnasi: Chaukambha Orientalia; 2005.

4. Vijitha Vijayan. A review of Kushmanda (Benincasa hispida) with special reference to Visha Chikitsa. The Pharma Innovation Journal. 2018. Available at https://www.thepharmajournal.com/archives/20 18/vol7issue12/PartE/7-11-96-168.pdf

5. Bhavamishra. Bhavaprakasha Nighantu Varanasi: Chaukambha Krishnadas Academy; 2011.

6. Benincasa hispida (Thunb.) Cogn. India Biodiversity Portal. Avialable at https:// indiabiodiversity.org/species/show/244546

7. Ministry of health and family welfare. Department of Ayush. Ayurveda Pharmacopeai of India. Part 1.Vol 4. Kushmanda. Page 55.

8. Susruta. Susrutha samhitha with Bhanumati comentary. Acharya VYadavji Trikamji, editor. Chowkhamba Sanskrit Series Office Varanasi; Reprint edition (1 January 2001)

9. Chandre, R., Upadhyay, B. N., \& Murthy, K. H. (2011). Clinical evaluation of Kushmanda Ghrita in the management of depressive illness. Ayu, 32(2), 230-233. 8520.92592 https://doi.org/10.4103/0974-

10. Kulkarni, R., Girish, K. J., \& Kumar, A. (2012). Nootropic herbs (Medhya Rasayana) in Ayurveda: An update. Pharmacognosy reviews, 6(12), 147153. https://doi.org/10.4103/0973-7847.99949 
11. Veni Bharti, Kiran, Surendra Kumar Sharma and Sumitra Singh, 2013. Evaluation of the Memory and Learning Improving Effects of Benincasa hispida Seeds in Mice. Pharmacologia, 4: 249-253.

12. Firke AR, Bobade RB. An Exploratory Clinical Trial to Evaluate Efficacy of Kushmanda (Benincasa hispida) for weight gain in Malnourished Children. J Ayu Herb Med 2019; 5(3): 87-89.

13. Majumdar A. Evaluation of Anti-nephrolithic \& Diuretic Activity of Seeds of Benincasa hispida R.Br. Inventi Rapid: Planta Activa Vol. 2012, Issue 3 Available at https://www.researchgate.net/ publication/315117711_Evaluation_of_Antinephrolithic_Diuretic_Activity_of_Seeds_of_Beninca sa_hispida_RBr

14. Grover JK, Adiga G, Vats V, Rathi SS. Extracts of Benincasa hispida prevent development of experimental ulcers. J Ethnopharmacol. 2001 Dec;78(2-3):159-64. doi: 10.1016/s0378-8741(01) 00334-8. PMID: 11694361.

15. Yoshizumia S, Murakami T, Kadoya M, et al. Medicinal food stuffs. XI. Histamine release inhibitors from wax gourd, fruits of Benincasa hispida Cogn. J Pharm Soc Jpn 1998; 118(5): 188192.

16. Benincasa hispida var, pruriens, Polynesian Wax Gourd, cited on 23rd October, 2011, available from http://www. articlesbase.com/alternativemedicine-articles/4478775
17. Kale K, Bharati PL, Panda AK, Yadav B et al. Clinical Efficacy and Safety of Kushmandaka Rasayana in the Management of Chronic Bronchitis: A Prospective Open Label Multicenter Study. J Res Ayurvedic Sci 2018 ;2(4): 225-232

18. Gupta Prerna et al. Ash gourd and its applications in the food, pharmacological and biomedical industries. International Journal of Vegetable Science 27(12): 1-10. December 2019. Available at https://www.researchgate.net/publication/33785 4043_Ash_gourd_and_its_applications_in_the_food_ pharmacological_and_biomedical_industries

19. Nandecha C, Nahata A, Dixit VK. Effect of Benincasa hispida fruits on testosterone-induced prostatic hypertrophy in albino rats. Curr Ther Res Clin Exp. 2010 Oct; 71(5): 331-43. doi: 10.1016/j.curtheres. 2010.10.006. PMID: 24688153; PMCID: PMC3969599.

20. Lee $\mathrm{KH}$, Choi HR, Kim CH. Anti-angiogenic effect of the seed extract of Benincasa hispida Cogniaux. J Ethnopharmacol. 2005 Mar 21; 97(3): 509-13. doi: 10.1016/j.jep.2004.12.008. PMID: 15740888.

21. Ali Esmail Al-Snafi. The Pharmacological Importance of Benincasa hispida. A review. International Journal of Pharma Sciences and Research (IJPSR) Available at http://www.ijpsr. info/docs/IJPSR13-04-12-007.pdf

\section{Cite this article as:}

Nimmy V S. A Comprehensive Review on the Nutritional and Medicinal Significance of Kushmanda or Ash Gourd as Per Ayurveda. International Journal of Ayurveda and Pharma Research. 2021;9(12):41-45.

https://doi.org/10.47070/ijapr.v 9i12.2215

Source of support: Nil, Conflict of interest: None Declared

\section{*Address for correspondence}

Dr. Nimmy V S

Assistant Professor,

Department of Dravyaguna

Vijnanam,

Vaidyaratnam Ayurveda College, Ollur, India.

Email: drvsnimmy@gmail.com

Disclaimer: IJAPR is solely owned by Mahadev Publications - dedicated to publish quality research, while every effort has been taken to verify the accuracy of the content published in our Journal. IJAPR cannot accept any responsibility or liability for the articles content which are published. The views expressed in articles by our contributing authors are not necessarily those of IJAPR editor or editorial board members. 